NBER WORKING PAPER SERIES

\title{
OPTIMAL ENVIRONMENTAL TAXATION IN THE PRESENCE OF OTHER TAXES: GENERAL EQUILIBRIUM ANALYSES
}

A. Lans Bovenberg

Lawrence $\mathrm{H}$. Goulder

Working Paper No. 4897

\author{
NATIONAL BUREAU OF ECONOMIC RESEARCH \\ 1050 inassachusetts Avenue \\ Cambridge, MA 02138 \\ October 1994
}

We are grateful to Jesse David and Steven Weinberg for excellent research assistance, and to the National Science Foundation (Grant SBR-9310362) and IBM Corporation for financial support. This paper is part of NBER's research program in Public Economics. Any opinions expressed are those of the authors and not those of the National Bureau of Economic Research.

(C) 1994 by A. Lans Bovenberg and Lawrence H. Goulder. All rights reserved. Short sections of text, not to exceed two paragraphs, may be quoted without explicit permission provided that full credit, including (c) notice, is given to the source. 
NBER Working Paper \#4897

October 1994

\title{
OPTIMAL ENVIRONMENTAL TAXATION \\ IN THE PRESENCE OF OTHER TAXES: \\ GENERAL EQUILIBRIUM ANALYSES
}

\begin{abstract}
This paper examines the optimal setting of environmental taxes in economies where other, distortionary taxes are present We employ analytical and numerical models to explore the degree to which, in a second best economy, optimal environmental tax rates differ from the rates implied by the Pigovian principle (according to which the optimal tax rate equals the marginal environmental damages). Both models indicate, contrary to what several analysts have suggested, that the optimal tax rate on emissions of a given pollutant is generally less than the rate supported by the Pigovian principle. Moreover, the optimal rate is lower the larger are the distortions posed by ordinary taxes. Numerical results indicate that previous studies may have seriously overstated the size of the optimal carbon tax by disregarding pre-existing taxes.
\end{abstract}

\author{
A. Lans Bovenberg \\ Center for Economic Research \\ Tilburg University \\ P.O. Box 90153 \\ 5000 LE Tilburg \\ THE NETHERLANDS
}

\author{
Lawrence H. Goulder \\ Department of Economics \\ Landau Building \\ Stanford University \\ Stanford, CA 94305-6072 \\ and NBER
}




\section{Introduction}

Most economies feature levels of public spending that require more tax revenues than would be generated solely from pollution taxes set according to the Pigovian principle, that is, set equal to marginal environmental damages. As a consequence, tax systems generally rely on both environmental (corrective) and other taxes. However, the tradition anong economists has been to analyze corrective and distortionary taxes separately: environmental taxes usually are examined without taking into account the presence of other. distortionary taxes. This omission is significant because the consequences of environmental taxes depend fundamentally on the levels of other taxes, including income and commodity taxes.

This paper examines optimal environmental taxation in a second-best setting. In particular, we explore how optimal environmental tax rates deviate from the rates implied by the Pigovian principle. The few previous investigations of this issue ${ }^{1}$ include Sandmo (1975), Lee and Misiolek (1986) and Oates (1991). Sandmo demonstrated how the well-known "Ramsey" formula for optimal commodity taxes is altered when one of the consumption commodities generates an extemality. Lee-Misiolek and Oates derive formulae indicating how the optimal rate for a newly imposed environmental tax is related to the marginal excess burden from existing taxes. The present paper extends this literature in three ways. First, in contrast with Sandmo's work, it derives analytical expressions for the optimal environmental tax in a more general setting that considers intemediate inputs as well as consumption commodities and incorporates both public and private goods in utility. Second, it differs from the papers of Lee and Misiolek and Oates in applying a general equilibrium analysis to link environmental and other taxes: distortionary costs of ordinary and environmental taxes are determined endogenously. Finally, in contrast with the earlier papers it combines the analytical work with numerical simulations that consider the implications of these principles for the U.S. economy.

The paper is organized as follows. Section II analytically investigates optimal environmental taxes using a simple general equilibriurn model. The next two sections explore these issues numerically employing a disaggregated intertemporal general equilibrium model. Section III describes the numerical model; Section IV applies this model to evaluate the departures from Pigovian tax rules implied by second-best considerations. The final section offers conclusions.

\footnotetext{
'A closely relared issue is the extent to which the costs of environmental taxes are lowered when revenues from such taxes are devoted to reductions in existing distortionary taxes. A key question is whether "rocycling" the revenues in this way can make the overall cost of the revenue-neutral policy zero ar negative. For discussions of this issue in the context of carton taxes, see Poterta (1993), Oates and Portmey (1992). Pearce (1991), and Stavins (1991). For numerical investigations with carbon taxes see, for example. Weyant (1993) and Goulder (1994).
} 


\section{Theoretical Issues and Analytical Results}

This section explores analytically how the presence of distortionary taxation affects the optimal setting of environmental taxes in the context of a simple model. Production is described by a constantretums-to-scale production function $F(N L, X, Y)$ with inputs of aggregate labor (the product of the number of households $N$, and per capita labor supply, $L$ ), a "clean" intermediate good $(X)$, and a "dirty" intermediate good $(h)$. Output can be used for public consumption $(G)$, for clean or dirty intermediate inputs, or for household consumption of a "clean" and "dirty" consumption good (per capita clean and dirty consumption is denoted by $C$ and $D$, respectively). Hence, commodity market equilibrium is given by

$$
F(N L X, Y)=G+X+Y+N C+N D
$$

We normalize units so that the constant rates of transformation between the five produced commodities are unity.

The representative household maximizes private utility subject to the budget constraint:

$$
\left(1+t_{C}\right) C+\left(1+t_{D}\right) D=\left(1-t_{L}\right) w L
$$

where $t_{C}$ and $t_{D}$ denote, respectively, the tax rates on clean and dirty consumption. The labor tax rate $t_{L}$, and the producer (before-tax) wage, $w$, yield the consumption (after-tax) wage, $(1-t / v w$. Environmental quality, $E$, deteriorates with the quantity used of ditty intermediate and ditty consumption goods; that is, $E=e(Y, N D)$ with $e_{r}, e_{N D}<0$, where subscripts denote partial derivatives. Private decision makers ignore environmental externalities.

The government budget constraint is:

$$
G=t_{1} X+t_{7} Y+t_{D} N D+t_{L} w N L
$$

where $t_{x}$ and $t_{y}$ stand for the taxes on clean and dirty intermediate inputs, respectively. We assume (without loss of generality ${ }^{2}$ ) that the clean consumption commodity is untaxed.

\footnotetext{
${ }^{2}$ See footnote 5 below.
} 
To derive the optimal tax rates, we solve the government's problem of maximizing household utility subject to the government budget constraint and decentralized optimization by firms and households. Private commodities are separable from public goods in household utility. Accordingly, the govemment adopts its four tax instruments $\left(t_{L}, t_{0}, t_{x}, f_{f}\right)$ to optimize:

$$
N V\left[\left(1+t_{D}\right) ;\left(1-t_{L}\right) w\right]+N W[G, e(Y, N D)]+\mu\left(t_{L} w N L+t_{D} N D+t_{X} X+t_{Y} Y\right)
$$

where $V$ represents household indirect utility of private goods, $W(G, E)$ is utility from public goods, and $\mu$ denotes the marginal disutility of raising one unit of public revenue.

\section{Optimal Taxes on Intermediate Goods}

Appendix A derives the optimal tax rates. The analysis reveals that the clean intermediate inputs should not be taxed (i.e., $t_{x}=0$ ). Hence, in the absence of environmental extemalities, net rather than gross output should be taxed. This an application of the well-known optimality of production efficiency derived by Diamond and Mirrlees (1971). They demonstrated that, if production exhibits constant returns io scale $^{3}$, an optimal tax system should not distor production. Intuitively, a tax on intermediate inputs is bome by the only primary factor of production, i.e. labor, and thus amounts to an implicit labor tax. From a revenue-raising point of view, the implicit labor tax is less efficient than an explicit tax on labor; whereas both taxes distort labor supply by reducing the consumption wage, only the input tax distorts the input mix into production.

The optimal tax on diny inputs amounts to (see equation [A.7] in Appendix A):

$$
t_{r}=\left[\frac{u_{E}\left(-e_{r}\right)}{u_{c}}\right] \frac{1}{\pi}
$$

In contrast to the tax on clean inputs, the tax on dirty inputs is positive as long as households value environmental quality (i.e. $u_{z}>0$ ). The term between square brackets on the right-hand side of ( 5 ) corresponds to the textbook Pigovian tax. $\eta$ is defined as the ratio of the marginal value of public revenue to the marginal utility of private income; it is often referred to as the marginal cost of public funds (MCPF). The MCPF term in (5) reveals how second-best considerations affect optimal environmental

\footnotetext{
'Under decreasing returns to scale. production efficiency continues to be optimal as long as a $100 \%$ profit tax
} is available. 
taxation It indicates in particular that the Pigovian tax is optimal only if $\eta$ equals unity. A unitary MCPF means that public funds are not scarcer than private funds (as is the case when lump-sum taxes and subsidies are available or when labor supply is completely inelastic). However, in a second-best world without lump-sum taxation, the MCPF typically differs from one. In particular, the higher is the MCPF, the lower is the optimal environmental tax. ceteris paribus.

The inverse relationship between the MCPF and the optimal environmental tax may seem surprising since revenues from the environmental tax can be used to reduce distortionary taxes. However, the crucial consideration here is bow the presence (as opposed to reduction) of distortionary taxes in the economy influences the costs of environmental taxes. The connection can be understood as follows. Absuracting from their environmental benefits, environmental taxes are more costly than altemative distortionary taxes. In particular, a tax on dirty intermediate inputs is more costly than a tax on net output (see Diamond and Mirriees [1971]). This is the case because, in contrast to a tax on net output, the pollution tax "distorts" the input mix into production. In this way, environmental taxes involve an excess cost over other distortionary taxes such as labor taxes, and this excess cost rises with the MCPF (see Bovenberg and de Moij. 1994). Hence, the higher the MCPF, the higher the environmental benefits need to be to offset the excess costs of environmental taxes. The optimal pollution tax balances the social opportunity cost of additional tax revenue against the social benefit from reduced pollution. $A$ higher MCPF means that the social opportunity cost of revenue is larger, hence the social benefits from pollution reduction have to be greater to justify a given environmental tax.

Another way of interpreting the negative impact of the MCPF on the optimal environmental tax is as follows. The government employs the tax system to accomplish simultaneously two objectives: namely, raising public revenues to finance public goods (other than the environment), and intemalizing pollution externalities (thereby protecting the public good of the natural environment). If public revenues become scarcer, as indicated by a higher marginal cost of public funds, the optimal tax system focuses more on generating revenues (through non-environmental taxes, which are more efficient from a revenue-raising point of view) and less on internalizing pollution extemalities.

High estimates for the marginal efficiency costs of the existing tax system (ie., the MCPF) have been used in suppon of pollution taxes (see, e.g., Oates [1991], and Pearce [1991]). However, these arguments ignore the costs of environmental taxes in terms of exacerbating pre-existing tax distortions.

\footnotetext{
"The word "distort" is in quotes to acknowledge the notion that the change in resource allocation may be justified once environmental benefits are taken into account.
} 
These additional costs of environmental taxes are likely to be especially large if the marginal efficiency costs of the existing tax system are substantial. Therefore, the higher the efficiency costs of the existing tax structure are, the higher the environmental benefits need to be in order to justify the additional costs of environmental taxes in terms of a less efficient mechanism for financing public spending. High estimates for the efficiency costs of existing taxes weaken rather than strengthen the case for environmental taxation.

\section{Optimal Taxes on Consumption}

The optimal tax on dirty consumption consists of two parts (see also Sandmo [1975]. Auerbach [1985], and Bovenberg and van der Ploeg (1994]). The first par, $t_{D}^{E}$. corrects for the environmental extemality (see expression (A.6] in Appendix A):

$$
t_{D}^{E}=\left[\frac{N u_{E}\left(-e_{D}\right)}{u_{C}}\right] \frac{1}{\pi}
$$

This term looks very similar to (5). It amounts to the Pigovian tax divided by the MCPF. The second part of the optimal tax on polluting consumption, $t_{D}^{D} \bar{D}_{D}-t_{D}^{E}$, is the distortionary (or revenue-raising) component of the tax. Together with the optimal labor tax, the optimal level of this distortionary component is determined on the basis of the familiar Ramsey formulas for raising revenues with the lowest costs to private incomes (see equations (A.12] and (A.13] in Appendix A). For example, if clean and dirty consumption are weakly separable from leisure and if utility is homothetic, uniform taxation of clean and dirty goods is optimal from the point of view of raising revenues with the smallest burden on private incomes. In this case, the optimal tax structure involves equal distortionary components of the two taxes on consumption. (In the case of the clean consumption commodity, the distortionary component is the only component.) Uniform distortionary taxes on consumption are equivalent to taxes on labor, thus the optimum is characterized by zero distortionary taxation of polluting consumptions ${ }^{5}$ In this case, the only nonzero component of the optimal tax on dirty consumption is the extemality-correcting part (6) (i.e.. $t_{D}{ }^{D}=0$ and $t_{D}=t_{D}{ }^{5}$ ).

With this particular itility structure, the MCPF is given by (see Bovenberg and van der Ploeg 'Of course. since uniform consumption taxes are equivalent to labor taxes, the optimum can also be achieved
through non-zero distortionary taxes $\infty$ both conswmption goods and lower labor taxes. 
[1994]):

$$
n=\left[1-\frac{t_{L}}{1-t_{L}} \theta_{L}\right]^{1}
$$

The MCPF thus exceeds unity if (1) the uncompensated wage elasticity of labor supply, $\theta_{L}$, is positive and (2) Pigovian taxes do not suffice to finance public consumption so that the distortionary tax on labor, $t_{t}$, is positive. These results are consistent with the literature on the MCPF surveyed in Ballard and Fullerton (1990). For public spending that is separable from consumer's choice on leisure and consurnption, this literanure finds that distorionary labor taxes raise the marginal costs of public spending above unity if the uncompensated wage elasticity of labor supply is positive. Combining (5), (6) and (7), we find that the same condition on the uncompensated elasticity determines whether distortionary labor taxes raise the marginal cost of (the collective good of environmental protection above its social benefit. This result depends on the separability assumptions regarding utility. If environmental quality were a close substitute for private consumption, compensated rather than uncompensated elasticites would govern the effect on the marginal cost of environmental protection (see Wildasin [1984]).

\section{Basic Features of the Numerical Model}

The relatively simple analytical model discussed above abstracts from some important elements of actual economies. In particular, that model is static and disregards capital markets. Moreover, it treats all production as involving constant rearns to scale. We consider these issues in the more complex numerical applied in this paper. This model has the atraction of capturing more realistically an actual economy.

This section sketches out the main features of the numerical model. Some details on the model's structure and parameters are offered in Appendix B. A more complete description is contained in Goulder (1992). Cruz and Goulder (1992) provide data documentation.

The model is an intertemporal general equilibrium model of the U.S. economy with international trade. It generates paths of equilibrium prices, outputs, and incomes for the U.S. economy and the "rest of the world" under specified policy scenarios. All variables are calculated at yearly intervals beginning in the 1990 benchmark year and usually extending to the year 2070 .

The model is unique in combining a fairly realistic treatment of the U.S. tax system, a detailed representation of energy production and demand, and attention to stationary-source and mobile-source 
emissions of major air pollutants. It incorporates quite specific tax instruments and addresses effects of taxation along a number of important dimensions; these include firms' investment incentives, equity values, and profits, ${ }^{6}$ and household consumption, saving and labor supply decisions. The specification of energy supply incorporates the nonrenewable nature of crude petroleum and natural gas and the transitions from conventional to synthetic fuels. The treatment of emissions is based on historical relationships between emissions and fuels used. processes employed, and levels of output.

\section{A. Industry and Consumer Good Disaggregation}

The model divides U.S. production into the 13 industries indicated in Table 1 . The energy industries consist of coal mining, crude petroleum and natural gas extraction, petroleum refining, synthetic fuels, electric utilities, and gas utilities. The model distinguishes the 17 consumer goods in Table 1.

\section{B. Producer Behavior}

\section{General Specifications}

In each industry, a nested production structure accounts for substitution between different forms of energy as well as between energy and other inputs. Each industry produces a distinct output $(X)$, which is a function of the inputs of labor $(L)$, capital $(K)$, an energy composite $(E)$ and a materials composite $(M)$, as well as the current level of invesment $(I)$ :

$$
X=f[g(L, K), h(E, M)]-\phi(I / K) \cdot
$$

The energy composite is made up of the outputs of the six energy industries, while the materials composite consists of the outputs of the other industries:

$$
\begin{aligned}
& E=E\left(\bar{x}_{2}, \bar{x}_{3}+\bar{x}_{4}, \bar{x}_{3}, \bar{x}_{6}, \bar{x}_{7}\right) \\
& M=M\left(\bar{x}_{1}, \bar{x}_{3}, \ldots, \bar{x}_{13}\right)
\end{aligned}
$$

where $\bar{x}_{i}$ ts a composite of domestically produced and foreign made input $i{ }^{\top}$ Industry indices correspond to those in Table 1.

Managers of firms choose input quantities and investment levels to maximize the value of the firm. The investment decision takes account of the adjustment (or installation) costs represented by $\phi(I / K) \cdot I$

GHere the model applies the assel price approach wo investment developed in Summers (1981).

'The functions $f, g$, and $h$, and the aggregation functions for the composites $E, M$, and $\bar{x}_{i}$, are CES and exhibit constant returns wo scale. Consumer goods are produced by combining outputs from the 13 industries in fixed propartions. 
in equation (8). $\phi$ is increasing in the rate of investment.

\section{Special Features of the Oil-Gas and Synfuels Industries}

The production structure in the oil and gas industry is somewhat more complex than in other industries to account for the nonrenewable nature of oil and gas stocks. The production specification is:

$$
X=\gamma(Z) f[g(L, K), h(E, M)]-\phi(I / K) \cdot I
$$

where $\gamma$ is a decreasing function of $Z$. the amount of cumulative extraction of oil and gas up to the beginning of the current period. This captures the idea that as $Z$ rises (or, equivalently, as reserves are depleted), it becomes increasingly difficult to extract oil and gas resources, so that greater quantities of $K, L, E$, and $M$ are required to achieve any given level of extraction (output). Increasing production costs ultimately induce oil and gas producers to remove their capital from this industry."

The model incorporates a synthetic fuel -- shale oil -- as a backstop resource, a perfect substitute for oil and gas. ${ }^{10}$ The technology for producing synthetic fuels on a commercial scale is assumed to become known in 2010. Thus, capital formation in the synfuels industry cannot begin until that year.

All domestic prices in the model are endogenous, except for the domestic price of oil and gas. The path of oil and gas prices follows the assumptions of the Stanford Energy Modeling Forum. "The supply of imported oil and gas is taken to be perfectly elastic at the world price. So long as imports are the marginal source of supply to the domestic economy, domestic producers of oil and gas receive the world price (adjusted for tariffs or taxes) for their own output. However, rising oil and gas prices stimulate investment in synfuels. Eventually, synfuels production plus domestic oil and gas supply together satisfy all of domestic demand. Synfuels then become the marginal source of supply, so that the

\footnotetext{
'\$ represents adjustment costs per unit of investment. This function is convex in $/ K$ (see Appendix B) and expresses the notion that installing new capital necessitates a loss of current ouput, as existing inputs ( $K, L, E$ and $M$ ) are diverted to install new capital.

The attention to resource stock effects distinguishes this model several other general equilibrium energy environmental models. Many equilibrium models treas the domestic oil \& gas industry as involving constant-returnsw-scale production, disregarding resource stock effects or fixed factors. In their global energy-environment model. Manne and Richels (1992) impose stock limits on resources such as oil and gas; however, these limits do not affecl production costs prior to the point where the resource is exhausted. (9).

${ }^{10}$ Thus, inputs 3 (oil\&gas) and 4 (synfuels) enter additively in the energy aggregation function shown in equation

"The world price is $\$ 24$ per barrel in 1990 and rises in real terms by $\$ 6.50$ per decade. See Gaskins and Weyant (1994).
} 
cost of synfuels production rather than the world oil price dictates the domestic price of fuels. ${ }^{12}$

\section{Household Behavior}

Consumption, labor supply, and saving result from the decisions of a representative household maximizing its intertemporal utility, defined on leisure and overall consumption in each period. The utility function is homothetic and leisure and consumption are weakly separable (see Appendix B). The household faces an intertemporal budget constraint requiring that the present vaiue of the consumption stream not exceed potential total wealth (nonhuman wealth plus the present value of potential labor income and net transfers). In each period, overall consumption of goods and services is allocated across the 17 specific categories of consumption goods or services shown in Table 1 . Each of the 17 consumption goods or services is a composite of a domestically and foreign-produced consumption good (or service) of that type. Households substitute between domestic and foreign goods to minimize the cost of obtaining a given composite.

\section{The Government Sector}

The government collects taxes, distributes transfers, and purchases goods and services (outputs of the 13 industries). The tax instruments include energy taxes, output taxes, the corporate income tax. property taxes, sales taxes, and taxes on individual labor and capital income. In the benchmark year. 1990, the govemment deficit amounts to approximately two percent of GNP. In the reference case (or stanus quo) simulation, the debt-GNP ratio is approximately constant over time. In the policy experiments. we require that real government spending and the path of real government debt follow the same path as in the reference case. To make the policy changes revenue-neutral, we accompany the tax rate increases that define the various policies with reductions in other net taxes, either on a lump-sum basis (increased exogenous transfers) or through reductions in the marginal rates of other taxes.

\section{E. Foreign Trade}

Except for oil and gas imports. imported intermediate and consumer goods are imperfect substitutes for their domestic counterparts. ${ }^{13}$ Import prices are exogenous in foreign currency, but the domestic-currency price changes with variations in the exchange rate. Expon demands are modeled as

\footnotetext{
${ }^{12}$ For details, see Goulder (1992).

${ }^{13}$ Thus, we adopt the assumption of Armington (1969).
} 
functions of the foreign price of U.S. exports and the level of foreign income (in foreign currency). The exchange rate adjusts to balance trade in every period.

\section{F. Modeling Pollution Emissions}

Recent extensions of the model enable it to project emissions of eight important pollutants: total suspended particles (TSP), sulphur oxides (SOX), nitric oxides (NOX), volatile organic compounds (VOC's), carbon monoxide (CO), lead (Pb), particulate matter (PM10), and carbon dioxide $\left(\mathrm{CO}_{2}\right)$.

The key parameters used to project emissions levels (under baseline assumptions or in response to a change of policy) are emissions factors. These factors are calculated based on detailed U.S. data on emissions rates for specific industrial processes and fuels. ${ }^{14}$

\section{G. Equilibrium and Growth}

The solution of the model is a general equilibrium in which supplies and demands balance in all markets at each period of time. Thus the solution requires that supply equal dermand for labor inputs and for all produced goods's , that firms' demands for loanable funds match the aggregate supply by households, and that the government's tax revenues equal its spending less the currem deficit. These conditions are met through adjustments in output prices, in the market interest rate, and in lump-sum taxes or marginal tax rates. ${ }^{16}$

Economic growth reflects the growth of capital stocks and of potential labor resources. The growth of capital stocks stems from endogenous saving and investment behavior. Potential labor resources are specified as increasing at an exogenous rate. ${ }^{17}$

\footnotetext{
14Te model includes fuel-based, output-based, and mobile-source based emissions factors. The fuel-based emissions factor $e f_{i, j}$ represents the rate of emissions of pollutant $i$ per unil of input of fuel $j$ used industry $k$. Fuelbased emissions factors do not account for all of the emissions of a given pollutant from a given industry. Industrial emissions over and above those that can be atributed to given fuels are deemed output-based. The outpus-based emissions factor $e_{-} o_{\text {is }}$ denotes the ratio of oulpul-related emissions of pollutant $l$ to the quantity of gross output from industry $k$. The mobile-source emissions factors e_ $m$, express the ratio of emissions $l$ from a given mobile source $k$ to the level of use of that source (vehicle). For details on data and methodology, see Goulder (1993).

${ }^{15}$ Since oil and gas synfuels are perfect substitutes, they generate a single supply-demand condition.

${ }^{16}$ Since agents are forward-looking, equilibrium in each period depends not only on current prices and taxes bul on future magnitudes as well.

"The growth of potential labor services is due to population growth and exogenous Harrod-neutral (laborembodied) technical progress. The latter is consistent with a steady state because we assume that technical progress applies both to the production of goods and the enjoyment of leisure.
} 


\section{Optimal Environmental Taxes in a Second-Best Setting: Numerical Results}

This section uses the model described in Section III to investigate numerically how second-best considerations influence optimal rates for environmentally motivated taxes. We compare the numerical results with optimal rates implied by the Pigovian formula and by the analytical model of Section Il.

\section{A. The Simulations}

We focus on the policy of a carbon tax. This is a tax on fossil fuels -- oil, crude oil, natural gas. and synfuels -- in proportion to their carbon content. Since carbon dioxide $\left(\mathrm{CO}_{2}\right)$ emissions generally are proportional to the carton content of these fuels ${ }^{12}$, a tax based on carton content is effectively a tax on $\mathrm{CO}_{2}$ emissions. ${ }^{19}$

We compare results under a carbon tax with results from a reference case or baseline simulation. In the reference case. all tax rates and other policy variables are maintained at the benchmark (1990) values. In the long run, the economy reaches a steady state: all quantities increase at a rate of two percent (govemed by the exogenous growth rate of effective labor), while relative prices are constant. Two features of the model prevent balanced growth in the shor and medium nun. First, the depletion of oil and gas reserves causes unit costs of domestic oil and gas supply to rise. In addition. as indicated in the previous section. the real prices of imported oil and gas increase in real terms. These features reduce over time the share of oil and gas consumption relative to overall consumption. As indicated in Figure 1 , rising costs of domestic oil and gas production lead to diminishing output of domestic oil and gas, while rising import prices eventually cause synfuels to replace conventional fuels.

\section{B. Marginal Costs and Benefits from Emissions Reductions}

Figure 2a shows the marginal welfare costs of $\mathrm{CO}_{2}$ emissions reductions. The emissions reductions are achieved through carbon taxes of different magnitudes. The marginal costs are obtained by dividing the change in welfare costs (as measured by the equivalent variation) by the change in emissions over successive increments to carton taxes. The marginal costs are calculated for two altemative uses of the revenues: namely, additional lump-sum transfers and reductions in the marginal

\footnotetext{
Le The efficiency of the combustion process can affect somewhat the ratio of carbon dioxide emissions to the carton content of a given fuel. However, this accounts for only slight variations in this ratio.

${ }^{19}$ Atmospheric $\mathrm{CO}_{2}$ is considered a principal anthropogenic contributor to the greenhouse effect. The carton tax thus has the potential to reduce the rate of greenhouse warming by curtailing $\mathrm{CO}_{2}$ emissions and slowing the rate of increase in atmosphertc $\mathrm{CO}_{2}$ concentrations.
} 
rates of the personal income tax. The horizontal axis in the figure is the percentage reduction in $\mathrm{CO}_{2}$ emissions from the baseline path Obviously, a given tax generates different percentage reductions at different times; we "average" these reductions by first taking the present value of the reductions (over an infinite time horizon). We then convert this number into the annual emissions reduction which, if increased every year at the steady-state rate of growth, yields the same present value. ${ }^{20}$ Figure $2 b$ shows the carton tax rates necessary to achieve given emissions reductions. ${ }^{21.22}$ Several findings emerge from the figures. First, marginal welfare costs rise with increases in carbon tax rates. This reflects rising costs of carton abatement. Second, the marginal welfare cost curve is lower in the case of personal income tax replacement: using the revenues to cut personal income tax rates decreases the distortionary costs of the income tax, thereby lowering the cost of this revenue-neutral policy relative to the altemative policy with lump-sun replacement.

Third, emissions reductions from the carton tax entail positive marginal costs -- even when carbon tax revenues are returned to the economy through cuts in marginal rates of the personal income tax. This indicates that, at the margin, a carbon tax is more costly than the personal tax it replaces. This result is consistent with the analysis of Section II. Further experiments with the numerical model consistently yield this oulcome. ${ }^{23}$

Fourth. the marginal welfare cost curves in Figure $2 \mathrm{a}$ intersect the horizontal axis at a positive value. In other words, incremental carbon taxes (or incremental emissions reductions) involve non-incremental costs. This result contrasts with what one would obtain from a traditional Pigovian tax analysis, which implicitly assumes an economy without any pre-existing taxes. The Pigovian analysis

\footnotetext{
${ }^{20}$ The approach is as follows. Let $E E$ represent the present value of emissions reductions over the infinite horizon, where reductions are discounted at the household's real after-tax rate of return. Then the annualized reduction is given by $E E^{*}(r-g) /(l+r)$, where $r$ is the long-run real after-tax interest rate and $g$ is the long-run real growth rate.

${ }^{21}$ If environmental damages are retated to concentrations, rather than emissions, it will generally be preferable to have rising, rather than constant, carbon tax rates. On this see Peck and Teisberg (1992).

${ }^{22}$ In fact we obtain two relationships between carton tax rates and emissions reductions: one in the case of lumpsum replacement and one in the case of personal tax replacement. But the two are so similar they are virtually indistinguishable when plotted. The relationships differ (abeit slightly) because the method of revenue replacement has a slight influence on emissions. A given carbon cax rate implies slightly larger emissions reducrions when revenue replacement is hump sum (because aggregate income and output fall more).

${ }^{25}$ In Goulder (1994), the numerical model of this paper is employed to examine the sources of the excess cost of a cartion tax over personal or corporate income taxes. That study identifies the carton tax's focus on intermediate inpuls as a key determinant of its excess costs, thus reinforcing the analytical results from Section $\square$ of the present paper.
} 
asserts that the manginal welfare cost from an environmental tax is equal to the tax rate; hence, the marginal cost approaches zero as the tax rate becomes small. Our finding that marginal welfare costs are non-zero for infinitesmal carbon tax rates reflects the presence of other tax distortions. We return to this issue below.

\section{Comparing the Pigovian Prescription with Results from the Analytical and Simulation Models}

An important result from Figure 2 is that under both forms of revenue replacement, the optimal rate for the environmental tax differs substantially from the rate that would prescribed by the Pigovian principle. Suppose, for example, that the marginal environmental benefits from reductions in $\mathrm{CO}_{2}$ were equal to $\$ 75 .^{24}$ The Pigovian principle would support a carbon tax of the same value. Our analysis indicates, however, that in the presence of distortionary taxation, such a tax is too high under either form of revenue replacement: the marginal welfare costs exceed the marginal benefits. With revenues used to cut personal tax rates, the optimal tax is about $\$ 48$ per ton. The optimal tax is even lower (about $\$ 13$ per ton) when revenues are replaced through lump-sum payments. In fact, under lump-sum replacement, it is never efficiency-improving to introduce a (non-negative) carbon tax If marginal benefits are below $\$ 55$ per ton!

Further comparisons of implied optimal tax rates are offered in Table 2 . The first column of this table indicates altemative possible values for the merginal environmental damages from $\mathrm{CO}_{2}$ emissions. The other columns contain the optimal carbon tax rates corresponding to these environmental damages.

The third column of Table 2 includes optimal rates implied by the analytical model. That model indicates that the optimal environmental tax rate is equal to the marginal environmental benefits from emissions reduction (or marginal damages from emissions) divided by the marginal cost of public funds $(\eta)$. It presumes a world in which other (distortionary) taxes are set optimally. This assumption differs from the realistic benchmark conditions of the economy to which the numerical model applies: nevertheless, it is instructive to observe the "optimal" rate implied by the analytical model for the U.S. economy. Simulation experiments with the numerical model indicate that the marginal cost of public

\footnotetext{
${ }^{2}$ To facilitate the discussion of optimal taxes, we drastically simplify the time dimension. We disregard dynamic issues such as changes through time in benefits and costs, and dynamic choices such as optimal changes through time in tax rates. Time aggregation makes it easier to isolate key relationships that should continue to hold when dynamic elements are given fuller consideration.
} 
funds is approximately 1.12.25 Suppose once again that the marginal environmental benefit from reductions in $\mathrm{CO}_{2}$ has a value of $\$ 75$. In that case, the analytical model calls for a carbon tax of about $\$ 67(\$ 75 / 1.12)$ if the entire tax system is optimal. ${ }^{26}$

The fourth and fifth columns of Table 2 show the optimal values generated by the simulation model. These optimal values are the tax rates that equate marginal costs and benefits from emissions reductions, using the information shown in Figure 2.

Importantly, both the analytical and mumerical models yield optimal tax rates dramatically lower than those implied by the Pigovian principle. The explanation for these differences was provided in Section Il. In a second-best setting, a given environmental tax generates larger non-environmental costs than it would in the absence of other, distortionary taxes: environmental taxes compound the distortions that existing factor taxes generate. Hence, the optimal environmental tax is lower than the rate implied by the Pigovian principle.

The numerical model yields optimal rates even lower than those endorsed by the analytical model. The complexity of the numerical model makes it difficult to identify the cause of this difference. However. an important potential source is the nature of the benchmark. The analytical model's formula for optimal environmental taxes presumes an economy in which all taxes are set optimally. The numerical model. in contrast, employs a benchmark which approximates the actual U.S. tax system in 1990. This benchmark is suboptimal (in an efficiency sense) because the marginal efficiency costs of various taxes are not equal. It is worthwhile exploring the extent to which numerical simulations of the carbon tax under more efficient benchmark conditions would involve lower marginal costs of given emissions reductions and thus generate optimal carbon taxes closer to those predicted by the analytical model.

We do this by constructing a counterfactual benchmark involving an "improved" initial configuration of taxes, and then deriving the optimal carbon tax in this counterfactual setting. Specifically, we create a counterfactual benchmark that is optimal according to the principles inherent in the analytical model. The optimized benchmark involves two changes relative to the original benchmark: (1) taxes on intermediate inputs, industry outputs, and consumer goods are eliminated, and (2) marginal tax rates on

\footnotetext{
${ }^{2}$ We calculate the marginal cost of public funds by scaling up the exogenous path of government spending by a factor slightly greater than 1 (namely, 1.005), and calculating the welfare impact when this spending increase is financed through increased personal income taxes. The MCPF is equal to EV/PV( $\triangle G)$, where EV is the welfare change (as measured by the equivalent variation) and $P V(\Delta G)$ is the present value of the change in government spending.

${ }^{20}$ Perhaps more precisely, this is the optimal tax rate that arises when the analytical model's optimal tax rule is applied using the marginal cost of public funds from the numerical model.
} 
capital and labor are adjusted so that the marginal welfare cost per dollar are the same for each tax. Thus, under the optimized benchmark, all existing taxes involve the same marginal excess burden per dollar of revenue (\$0.22).

Figure 2 and Table 2 include results from a carbon tax that is imposed on this optimized benchmark. Figure 2a shows that under this counterfactual scenario the marginal welfare costs of given emissions reductions are significantly lower than under the realistic case. Correspondingly, in Table 2 the optimal carbon tax associated with given marginal environmental damages is higher than the optimal tax arising in the realistic benchmark case. By comparing the results in the third and last columns of Table 2. we find that under the optimized benchmark the simulation model yields optimal tax rates quite close to those endorsed by the analytical model. This indicates that most of the differences between the analytical and simulation model results are due to the "suboptimal" nature of the ordinary benchmark for the simularion model. ${ }^{27}$

\section{Sensitivity Analysis}

Table 3 indicates the sensitivity of optimal tax rates to key parameters. These simulations involve changes relative to the realistic (as opposed to optimized) benchmark. The table reports results based on a posited value of $\$ 75 /$ ton for the marginal environmental benefits from the carton tax. All results in the table are for simulations in which carbon tax revenues are retumed to the economy through reductions in personal income tax rates.

The general result from Table 3 is that, under the range of paraneter values considered, the analytical and numerical models call for optimal tax rates below the Pigovian optimum. The analytical optimum is below the Pigovian optimum because the MCPF consistently exceeds unity. The numerical optimum is always below the analytical optimum; as discussed previously, this seems to reflect the suboptimal nature of the benchmark.

To consider the significance of pre-existing tax rates (heading 2), we reduce or increase all marginai tax rates for pre-existing tax rates by 50 percent. The MCPF approaches unity as the pre-existing

\footnotetext{
${ }^{n}$ One could argue that in fact the current tax system is less imperfect than suggested by the non-zero intercept of the middle line in Figure 2a. The anstytical model indicates that the optimal second-best tax system has zero taxes on intermediate goods and on clean consumer goods. However, in the real world non-zero taxes on intermetiate goods and clean consumer goods need not constitute departures from optimality. To the extent that certain consumer good taxes are in fact user fees or are aimed at internalizing ocher environmental externalities, the additional marginal welfare costs they generate may be justified by the benefits of the specific goods, services, or environmental improvements they finance. Because the simulation model does not capture these benefits. it may overstate the marginal welfare costs of carbon emissions reductions.
} 
tax rates are reduced; accordingly, the optimal tax rates from the analytical and simulation models approach the Pigovian rate of \$75/ton

The intertemporal elasticity of substitution in consumption regulates the sensitivity of household savings to the after-tax retum. Larger values for this elasticity raise the MCPF (and thus decrease the optimal tax from the analytical model). The optimal tax from the simulation model is also lower in this case, implying that the revenue-neutral carbon tax package exacerbates distortions of the capital market, despite the fact that its revenues are retumed (in part) through reductions in capital income taxes.

The uncompensated elasticity of labor supply regulates the potential for distortions in labor markets. A higher value for this elasticity raises the MCPF (and reduces the optimal tax from the analytical model). However, a higher elasticity of labor supply implies a higher optimal tax from the numerical model. Hence, the revenue-neutral combination of a carbon tax and a personal tax cut tends to reduce labor market distortions. This suggests that the carton tax primarily distorts the intertemporal margin while the personal tax (for which labor income contributes 70 percent of the revenues) distorts mainly the labor-leisure margin.

Higher values for energy substiturion elasticities enlarge the potential for distortions in energy markets. With higher elasticities the MCPF is higher and the analytical optimum is lower. The numerical model's optimum is also lower in this case. The revenue-neutral combination of carbon tax and personal tax cut thus exacerbates inefficiencies (abstracting from environmental benefits) in energy markets.

\section{v. Conclusions}

This paper has employed analytical and numerical models to examine the general equilibrium interactions between environmentally motivated taxes and distortionary taxes. Our results indicate that accounting for pre-existing taxes yiclds optimal tax rates considerably below the rates suggested by the Pigovian principle. This may seem to contradict the notion, expressed by several authors, that optimal tax rates can be higher if environmental tax revenues are retumed to the economy through cuts in distortionary taxes, rather than in lump-sum fashion. In fact, there is no contradiction here; different reference points apply. We too find that (for given marginal environmental benefits) the optimal tax is higher with revenue replacement through cuts in distortionary taxes than with replacement through increased lump-sum transfers (larger lump-sum tax reductions). But we also find that the optimal rate under either type of revenue replacement is considerably lower in a second-best economy compared with the result for the same type of revenue replacement in an economy without distortionary taxes.

In this connection, estimates of optimal carton taxes in integrated climate-economy models (e.g., 
Nordhaus [1993] ${ }^{28}$, and Peck and Teisberg [1992]) are biased upward. For example, Nordhaus (1993) considers how recycling carbon tax revenues through cuts in distortionary taxes raises the optimal carbon tax. When revenues from the carbon tax are retumed in lump-sum fashion, the optimal tax rate for the first decade is about $\$ 5$ per ton; the optimal rate rises to $\$ 59$ per ton when revenues are devoted to reducing distortionary taxes. Importantly, that study does not consider how pre-existing taxes increase the gross costs of the carton tax itself (before the revenues are recycled). While the Nordhaus study accounts for the efficiency gains connected with the reduction (through recycling) of initial distortionary taxes, it does not consider the efficiency costs stemming from the interactions between remaining distortionary taxes and the newly imposed carbon tax. The analytical and simulation models in this paper indicate that the costs associated with (remaining) pre-existing distortions are greater than the benefits from reductions in distorionary taxes made possible by the carbon tax revenues. Hence, pre-existing taxes reduce the optimal tax rate.

These results provide some guidelines on the setting of environmental taxes. At the same time, it should be emphasized that in many circumstances a key ingredient in the optimal tax formulation -- the marginal environmental benefits -- is very uncertain. Further research that narrows the uncertainty bands will be of great value to policy analysts.

"Nordhaus has pioneered the integration of (environmental) benefits and (non-environmental) costs in simulation modeling of carbon taxes. 


\section{References}

Armington, P.S., 1969. "A Theory of Demand for Products Distinguished by Place of Production," IM.F. Staff Papers, 159-76.

Auerbach. A.J., 1985. "The Theory of Excess Burden and Optimal Taxation," in A.J. Auerbach and M.S. Feldstein (eds.), Handbook of Public Economics 1, North-Holland, Amsterdam.

Ballard, C.L. and D. Fullerton, 1990. "Wage Tax Distortions and Public Good Provision, National Bureau of Economic Research Working Paper No. 3506, Cambridge, MA.

Bovenberg, A.L. and F. van der Ploeg. 1994. "Environmental Policy, Public Finance and the Labor Market in a Second-Best World," Journal of Public Economics, forthcoming.

Bovenberg, A.L. and R.A. de Mooij, 1994. "Environmental Levies and Distortionary Taxation." American Economic Review, forthcoming.

Cruz, Miguel and Lawrence H. Goulder, 1992. "An Intertemporal General Equilibrium Model for Analyzing U.S. Energy and Environmental Policies: Data Documentation." Unpublished manuscript, Stanford University.

Diamond, P.A., and J.A. Mirrlees, 1971. "Optimal Taxation and Public Production, American Economic Review $61,8-27$ and 261-278.

Gaskins, Darius and John Weyant, 1994. The Costs of Controlling Greenhouse Gas Emissions. Stanford, CA: Stanford University Press, forthcoming.

Goulder, Lawrence H., November 1992. "An Intertemporal General Equilibrium Model for Analyzing U.S. Energy and Environmental Policies: Model Structure." Unpublished manuscript, Stanford University.

1993. "Energy Taxes: Traditional Efficiency Effects and Environmental Implications." In James M. Poterba, ed. Tax Policy and the Economy 8. Cambridge, MA. MIT Press, forthcoming.

1994. "Effects of Carton Taxes in an Economy with Prior Tax Distortions: An

Intertemporal General Equilibrium Analysis." Working Paper, Stanford University.

and Philippe Thalmann, 1993. "Approaches to Efficient Capital Taxation: Leveling the Playing Field vs. Living by the Golden Rule.". Journal of Public Economics 50, 169-196.

Lee, Dwight R, and Walter S. Misiolek, 1986. "Substituting Pollution Taxation for General Taxation: Some Implications for Efficiency in Pollution Taxation." Journal of Environmental Economics and Management 13:338-347.

Manne, Alan S., and Richard G. Richels, 1992. Buying Greenhouse Insurance: The Economic Costs of $\mathrm{CO}_{2}$ Emissions Limits. Cambridge, MA, MIT Press. 
Masters, Charles D., ef al., 1987. "World Resources of Crude Oil. Natural Gas, Natural Bitumen, and Shale Oil." in Proceedings of the 12th World Petroleum Congress 5, 3-27.

Nordhaus, William D., 1993. "Optimal Greenhouse-Gas Reductions and Tax Policy in the "D1CE" Model." American Economic Review (Papers and Proceedings) 83 (2), 313.317.

Oates, W.E., 1991. "Poliution Charges as a Source of Public Revenues," Resources for the Future Discussion Paper No. QE92-05. Washington, D.C.

Oates, W.E.. and Paul R. Pormey, 1992. "Economic Incentives and the Containment of Global Warming." Easiern Economic Journal 18(1), 85-98.

Pearce. D.W., 1991. "The Role of Carbon Taxes in Adjusting to Global Warming. " Economic Journal 101, 938-948.

Peck, Stephen C. and Teisberg. Thomas J.. 1992. "CETA: A Model for Carbon Emissions Trajectory Assessment." Energy Journal 13 (1), 55-77.

Poterba. James M. and Lawrence H. Summers, 1985. "The Economic Effects of Dividend Taxation." In Edward I. Altman and Mari G. Subramanyam, eds.. Recent Advances in Corporase Finance. Homewood, II. Irwin

Poterba, James M., 1993. "Global Warming: A Public Finance Perspective." Journal of Economic Perspectives 7(4), 47-63.

Sandmo, A., 1975. "Optimal Taxation in the Presence of Externalities." Swedish Journal of Economics 77, 86-98.

Stavins, Robert N., 1991. Project 88 -- Round II. Incentives for Action: Designing Market-Based Environmental Strategies. Washington, D.C., May.

Summers, Lawrence H., January 1981. "Taxation and Corporate Investment: A q-Theory Approach." Brookings Papers on Economic Activity, 67-127.

Weyant, John P., 1993. "Costs of Reducing Global Carbon Emissions." Journal of Economic Perspectives 7(4), $27-46$.

Wildasin, D.E., 1984, "On Public Good Provision with Distortionary Taxation." Economic Inquiry 22, 227-243. 


\section{Appendir A: Analytical Results}

Firms maximize profits under perfect competition and thus equalize the marginal product of each factor to its user cost.

$$
\begin{aligned}
& F_{N L}(1, X / N L, Y / N L)=w \\
& F_{X}(1, X / N L, Y / N L)=1+t_{X} \\
& F_{Y}(1, X / N L, Y / N L)=1+t_{Y}
\end{aligned}
$$

The last two first-order conditions yield the demands for the two intermediate inputs conditional on the level of employment.

$$
X=N L x\left(1+t_{x} ; 1+t_{y}\right) ; \quad Y=N L y\left(1+t_{x} \mid 1+t_{y}\right)
$$

Substituting (A.2) into the first first-order condition in (A.1), we find the producer wage in terms of $t_{x}$ and $t_{r}$ :

$$
w=\omega\left(1+t_{\dot{x}} 1+t_{r}\right)
$$

where

$$
\omega_{t_{\mathrm{r}}}=-\frac{X}{N L} ; \quad \omega_{\iota,}=-\frac{Y}{N L}
$$

To find the optimal tax rates, we substitute (A.2) into (4) to eliminate $X$ and $Y$. Maximizing with respect to $t_{L}$, we find the following first-order condition (after dividing through by $-w N$ ).

$$
(\lambda-\mu) L+\mu\left[t_{D} \frac{\partial D}{\partial w_{N}}+\left(t_{L} w+t_{x}+t_{r}\right) \frac{\partial L}{\partial w_{N}}\right]+N u_{E} e_{N D} \frac{\partial D}{\partial w_{N}}+u_{E} e^{e} \frac{\partial L}{\partial w_{N}}=0
$$

where we have used $\frac{\partial V}{\partial w_{N}}=\lambda L$ (Roy's identity) and where $w_{N}=\left(1-t_{L}\right) w$. Define

$$
\begin{aligned}
& t_{D}^{E}=\frac{N u_{E}\left(-e_{D}\right)}{\mu} \\
& t_{r}^{E}=\frac{u_{E}\left(-e_{r}\right)}{\mu}
\end{aligned}
$$


Substitution of (A.6) and (A.7) into (A.5) yields

$$
(\lambda-\mu) L=\mu\left[\left(t_{t}-t_{D}^{E}\right) \frac{\partial D}{\partial w_{N}}+t_{t} w \frac{\partial L}{\partial w_{N}}\right]+\mu\left[t_{x}+\left(t_{Y}-t_{Y}^{E}\right)\right] \frac{\partial L}{\partial w_{N}}
$$

The first-order condition for maximizing (4) with respect to $t_{x}$ is given by:

$$
\begin{gathered}
\mu\left[X+t_{x} N L \frac{\partial x}{\partial t_{x}}+\left(t_{Y}-t_{Y}^{E}\right) N L \frac{\partial y}{\partial t_{x}}\right] \\
+\mu w_{t_{r}} N L\left[t_{x} \frac{\partial x}{\partial w}+\left(t_{Y}-t_{r}^{E}\right) N L \frac{\partial y}{\partial w}\right]-w_{t_{A}} \mu N L=0
\end{gathered}
$$

where we have used (A.6), (A.7) and (A.8). Substitution of (A.4) yields:

$$
t_{x}\left[\frac{\partial x}{\partial t_{x}}-\frac{X}{N L} \frac{\partial x}{\partial w}\right]+\left(t_{y}-i_{r}^{E}\right)\left[\frac{\partial y}{\partial t_{Y}}-\frac{X}{N L} \frac{\partial y}{\partial w}\right]=0
$$

In an analogous way, we derive the first-order condition for $t_{r}$ as:

$$
t_{x}\left[\frac{\partial x}{\partial t_{y}}-\frac{Y}{N L} \frac{\partial x}{\partial w}\right]+\left(t_{r}-t_{y}^{E}\right)\left[\frac{\partial y}{\partial t_{\gamma}}-\frac{Y}{N L} \frac{\partial y}{\partial w}\right]=0
$$

(A.10) and (A.11) together imply $t_{x}=0$ and $t_{r}=t_{Y}^{E}$. With (A.7), this implies (5), where $\eta=\mu / u_{c}$. Substitution of these results into (A.8) and the first-order condition for $t_{D}$ yields:

$$
\begin{aligned}
& (\lambda-\mu) L+\mu\left[\left(t_{D}-t_{D}^{E}\right) \frac{\partial D}{\partial w_{N}}+t_{L} w \frac{\partial L}{\partial w_{N}}\right]=0 \\
& (\lambda-\mu) D+\mu\left[\left(t_{D}-t_{D}^{E}\right) \frac{\partial D}{\partial t_{D}}+t_{L} w \frac{\partial L}{\partial t_{D}}\right]=0
\end{aligned}
$$

(A.12) and (A.13) are the familiar Ramsey equations in which the term $t_{D}$ is replaced by the distortionary part of the tax on polluting consumption, $t_{D}^{D}=t_{D}-t_{D}^{E}$. The non-distortionary part is given by (A.6), which can be written as (6) by using the definition of $\eta\left(\equiv \mu / u_{c}\right)$. 
Appendix B: Structure and Parameter Values of the Numerical Model'

\section{Structure}

\section{A. Production \\ 1. Technology \\ a General Features}

Table $\mathrm{A} /$ indicates the nested production structure. In each industry $i$, gross output $X_{\mathrm{i}}$ is produced using inputs of labor $\left(L_{i}\right)$, capital $(K)$, an energy composite $\left(\bar{E}_{f}\right)$ and a materials composite $\left(\bar{M}_{p}\right)$. The production function has the following form:

$$
X_{i}=f_{i}\left[g_{1 i}\left(L_{i}, K_{1}\right), g_{2 j}\left(\bar{E}_{i}, \bar{M}_{i}\right)\right]-\phi_{1}\left(l / K_{i}\right) I_{1}
$$

The functions $f_{i}, g_{i i}$, and $g_{i i}$ are CES. Hence the function $f$ can be written as:

$$
f\left(g_{1}, g_{2}\right)=\gamma_{j}\left(\alpha, g_{1}^{p_{j}}+\left(1-\alpha_{j}\right) g_{2}^{p_{r}}\right]^{1 / p_{r}}
$$

where the industry subscript has been suppressed and where $\gamma_{f}, \alpha_{f}$ and $\rho_{f}$ are parameters. The parameter $\rho$ is related to $\sigma_{j}$, the elasticity of substitution between $g_{1}$ and $g_{2}: \rho=(\sigma-l) / \sigma$. Analogous expressions apply for the functions $g$, and $g$ :

The second term in equation (1) represents the loss of output associated with installing new capital (or dismantling existing capital). Per-unit adjustment costs, $\phi$, are given by:

$$
\phi(I / K)=\frac{(\xi / 2)(I / K-\delta)^{2}}{I / K}
$$

where $I$ represents gross investment (purchases of new capital goods) and $\xi$ and $\delta$ are parameters. The parameter $\delta$ denotes the rate of economic depreciation of the capital stock.

The energy composite $\left(\bar{E}_{f}\right)$ in equation $(1)$ is a CES function of the specific energy products of the different energy industries:

$$
\bar{E}=\bar{E}\left(E_{1}, E_{2} \ldots, E_{3}\right)
$$

4b)

$$
=\gamma_{\bar{E}}\left[\sum_{j=1}^{3} \alpha_{\bar{E}} E_{j}^{\rho_{j}}\right]^{1 / \rho_{j}}
$$

'A more comprehensive description of the structure of the model is in Goulder (1992). Detailed documentation of the data and parameters for the model is provided in Cruz and Goulder (1992). 
Table Al: Nested Production Structure

\begin{tabular}{|c|c|c|c|}
\hline$X$ & $=$ & $f\left(g_{1} \cdot g_{2}\right)-\phi(I / K) I$ & \\
\hline$g$ & $=$ & $g_{1}(L, K)$ & \\
\hline$g$ & $=$ & $g_{2}(E, M)$ & \\
\hline$E$ & $=$ & $E\left(E_{1}, \ldots, E_{S}\right)$ & \\
\hline$M$ & $=$ & $M\left(M_{1}, \ldots, M.\right)$ & \\
\hline$E_{i}$ & $=$ & $E_{l}(E D, E F)$ & $i=1, \ldots, 5$ \\
\hline$M_{i}$ & $=$ & $M_{j}\left(M D_{,}, M F\right)$ & $i=1, \ldots, 7$ \\
\hline
\end{tabular}

Note: $\quad$ All functions are CES in form except for $\phi(I / K)$, which is quadratic in $l / K$.

Table A2: Nested Utility Structure

Function:

\section{Functional Form:}

$U_{1}\left(C_{1}, C_{1,1}, \ldots, C_{1}, \cdots\right)$ constant intertemporal elasticity of substitution

$C_{1}\left(e_{1}, l_{s}\right)$ CES

$e_{s}\left(\overline{\mathrm{C}}_{\mathrm{i} .1}, \ldots, \overline{\mathrm{C}}_{i, 1}, \ldots, \overline{\mathrm{C}}_{17.8}\right)$

Cobb-Douglas

$\overrightarrow{\mathrm{C}}_{1,1}\left(\mathrm{CD}_{\mathrm{i},}, \mathrm{CF}_{\mathrm{i, \Omega}}\right)$

CES

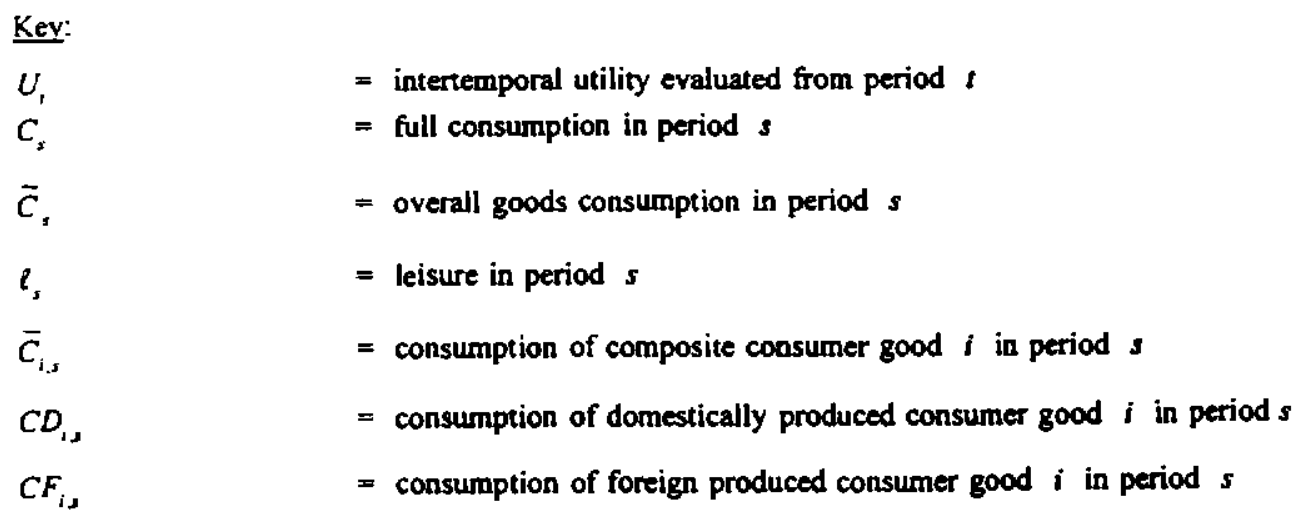


where $\sum_{j=1}^{s} \alpha_{\bar{E} j}=1$. The subscripts to $\mathrm{E}$ in equations (4a) and (4b) correspond to energy industries as follows:

$\underline{\text { Subscript }}$

1
2
3
4
5

Energy Industry

Coal mining

Oil\&gas extraction and synthetic fuels

Petroleum refining

Electricity

Processed natural gas

Oil\&gas and synthetic fuels combine as one input in the energy composite, reflecting the fact that these fuels are treated as perfect substitutes in production. ${ }^{2}$

Similarly, the materials composite $\left(\bar{M}_{1}\right)$ in equation $(1)$ is a CES function of the specific materials products of the 7 non-energy industries:

$$
\bar{M}=\bar{M}\left(M_{1}, M_{2}, \ldots, M_{1}\right)
$$

$$
=\gamma_{\bar{M}}\left[\sum_{j=1}^{T} \alpha_{\bar{M}} M_{j}^{p_{j}}\right]^{1 / p_{\dot{L}}}
$$

where $\sum_{j=1}^{t} \alpha_{\bar{i} j}=1$. The subscripts to $M$ in equations (5a) and (5b) correspond to materials (non-energy) industries as follows:

\section{Subscript}

1
2
3
4
5
6
7

\section{Materials Industry}

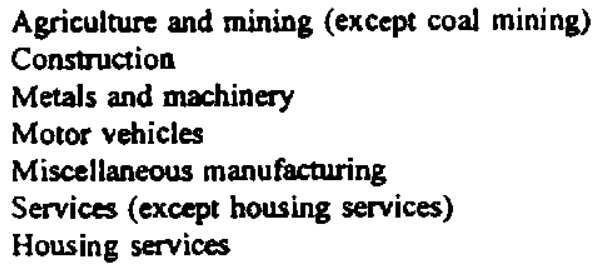

The elements $E_{j}(j=l, \ldots, 5)$ and $M_{j}(j=1, \ldots, 7)$ in the $\bar{E}$ and $\bar{M}$ functions are themseives CES composites of domestically produced and foreign made inputs:

$$
\begin{aligned}
& E_{j}=\gamma_{E j}\left[\alpha_{E j} E D_{j}^{D_{E j}}+\left(1-\alpha_{E j}\right) E F_{j}^{P_{\alpha}}\right]^{1 / D_{E Q}}, j=1, \ldots, 5
\end{aligned}
$$

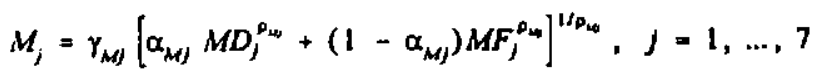

\footnotetext{
'E $E_{2}$ denotes the total quantity (in energy-equivalent units) of oil\&gas plus synfuels:

$$
E_{2}=E_{\text {os }}+E_{*}
$$
}


where $E D$, and $E F$, denote domestic and foreign energy inputs of type $j$, and $M D$, and $M F$, denote domestic and foreign materials inputs of type $j$.

\section{b. Endogeneity of $\gamma$ in the Oil\&Gas Production Function}

In industries other than oil\&gas, the element $\gamma$ in the production function is parametric. In the oil\&gas industry, $\gamma_{f}$ is a decreasing function of cumulative oil\&gas extraction:

$$
y_{1,1}=\varepsilon_{1}\left[1-(Z, / \bar{Z})^{\varepsilon_{2}}\right]
$$

where $\epsilon_{1}$ and $\epsilon_{2}$ are parameters, $Z$, represents cumulative extraction as of the beginning of period $t_{1}$ and $\bar{Z}$ is the original estimated total stock of recoverable reserves of oil\&gas (as estimated from the benchmark year). The following equation of motion specifies the evolution of $Z_{1}$ :

$$
Z_{1-1}=Z_{1}+X_{1}
$$

Equation (8) implies that the production function for oil and gas shifts downward as cumulative oil\&gas extraction increases. This addresses the fact that as reserves are depleted, remaining reserves become more difficult to extract and require more inputs per unit of extraction.

\section{Behavior of Firms}

In each industry. managers of firms are assumed to serve stockholders in aiming to maximize the value of the firm. The objective of firm-value maximization determines firms' choices of input quantities and investment levels in each period of time.

The value of the firm can be expressed in terms of dividends and new share issues, which in turn depend on profits in each period. The firm's profits during a given period are given by:

$$
\pi=\left(1-\tau_{a}\right)\left[p X-w\left(1+\tau_{L}\right) L-E M C O S T-i D E B T-T P R O P\right]+\tau_{a}(D E P L+D E P R)
$$

where $r_{a}$ is the tax rate on profits, $p$ is the output price net of output taxes, $w$ is the wage rate net of indirect labor taxes, $\tau_{\mathrm{L}}$ is rate of the indirect tax on labor, EMCOST is the cost to the firm of energy and materials inputs. $i$ is the gross-of-tax interest rate paid by the firm, DEBT is the firm's current debe, TPROP is property tax payments, $D E P L$ is the current gross depletion allowance, and $D E P R$ is the current gross depreciation allowance. TPROP equals $\tau_{p} p_{K, 1} K_{x}$. where $\tau_{p}$ is the property tax rate, $p_{k}$ is the purchase price of a unit of new capital, and $s$ is the time period. Current depletion allowances, $D E P L$, are a constant fraction $\beta$ of the value of current extraction: $D E P L=\beta p X$. Current depreciation allowances, $D E P R$, can be expressed as $\delta^{T} K^{T}$, where $K^{T}$ is 
the depreciable capital stock basis and $\delta^{T}$ is the depreciation rate applied for tax purposes.

In equation (10), EMCOST is given by:

$$
E M C O S T=\sum_{j=1}^{s}\left(1+\tau_{E j}\right)\left(p_{E D, j} E D_{j}+p_{E F j} E F_{j}\right)
$$

$$
+\sum_{j=1}^{T}\left(1+\tau_{m j}\right)\left(p_{M D_{j}} M D_{j}+p_{M \sigma J} M F_{j}\right)
$$

where the subscripts for energy and materials correspond to industries as indicated above; and where $\tau_{E}$ and $\tau_{M}$ denote the tax rates applying to the firm's use of intermediate inputs, and $p_{E D J}$ and $p_{E F,}\left(p_{M D_{j}}\right.$ and $\left.P_{M F_{J}}\right)$ are the pre-tax prices of domestic and foreign energy (materials) inputs of type $j$.

The following accounting or cash-flow identity links the firm's sources and uses of revenues: .

$$
\pi+B N+V N=D I V+I E X P
$$

The left-hand side is the fim's source of revenues: profits, new debt issue $(B N)$, and new share issues $(V N)$. The uses of revenues on the right-hand side are investment expenditure (IEXP) and dividend payments (DIV). Negative share issues are equivalent to share repurchases, and represent a use rather than source of revenue.

Firms pay dividends equal to a constant fraction, $a$, of profits net of economic depreciation, and maintain debt equal to a constant fraction, $b$, of the value of the existing capital stock. Thus:

$$
\begin{gathered}
D I V_{s}=a\left[\pi_{s}+\left(p_{X_{,},}-p_{X, s-1}\right) K_{s}-\delta p_{X_{s},} K_{s}\right] \\
B N_{s} \equiv D E B T_{s, 1}-D E B T_{s}=b\left(p_{X, s} K_{,, 1}-p_{X, s-1} K_{s}\right)
\end{gathered}
$$

Investment expenditure is expressed by:

$$
I E X P_{,}=\left(1-\tau_{x}\right) P_{x, s} l,
$$

where $\tau_{x}$ is the investment tax credit rate. Of the elements in equation (12), new share issues, $V N$, are the

\footnotetext{
'For convenience, we assume that the accelerated depreciation schedule can be approximated by a schectule invoiving constant exponential tax depreciation.

'To simplify the exposition, we have not included in equations (10) and (11) subscripts identifying the given industry for which profits or input costs are calculated. It may be noted that the intermediate good taxes, $\tau_{\varepsilon j}$ and $\tau_{M G}$, may differ across industries using a particular good as well as across intermediate goods.

In equation $(11)$, for $j=2$ the expression $p_{\varepsilon}\left(I+\tau_{\varepsilon}\right) E_{j}$ is short-hand for $p_{o g}\left(I+\tau_{o g}\right) E_{o q}+p_{y g}(I$ $+\tau_{j} E_{y}$, where "og" refers to oil and gas and " $s f$ " refers to synfuels. Since oil\&gas and synfuels are perfect substitutes, it is always the case that gross-of-tax costs of these fuels to the firm are the same: that is, $p_{u r}\left(I+\tau_{o f}\right.$ $=p_{s}\left(I+\tau_{y}\right)$. However, when $\tau_{o g} \neq \tau_{y j}$, the net-of-tax prices $p_{a g}$ and $p_{q}$ will differ.
} 
residual, making up the difference between $x+B N$ and $D I V+I E X P$ ?

Arbitrage possibilities compel the firm to offer its stockholders a rate of return comparable to the rate of interest on alternative assets.

$$
\left(1-\tau_{c}\right) D I V,+\left(1-\tau_{v}\right)\left(V_{n+1}-V_{,}-V N_{,}\right)=\left(1-\tau_{b}\right) i, V_{,}
$$

The parameters $\tau_{,}, \tau_{1}$, and $\tau_{h}$ are the personal tax rates on dividend income (equity), capital gains, and interest income (bonds), respectively. The return to stockholders consists of the current after-tax dividend plus the after-tax capital gain (accrued or realized) on the equity value $(V)$ of the firm net of the value of new share issues. This return must be comparable to the after-tax return from an investment of the same value at the market rate of interesh. i.

The firm's decision problem is completed by the equation of motion for the capital stock:

$$
K_{, .1}=(1-\delta) K_{x}+I,
$$

Capital is augmented by net investment. Cumulative extraction is augmented by the level of current output (or extraction). In the oil\&gas industry, the equation of motion (9) also applies.

\section{B. Household Behavior}

Consumption, labor supply, and saving result from the decisions of an infinitely-lived representative household maximizing its intertemporal utility with perfect foresight. The nested structure of the household's utility function is indicated in Table A2. In year I the household chooses a path of "full consumption" $C$ to maximize

$$
U_{1}=\sum_{1=1}^{\infty}(1+\omega)^{\prime} \cdot \frac{\sigma}{\sigma-1} C_{1}^{\frac{\sigma-1}{\sigma}}
$$

where $\omega$ is the subjective rate of time preference and $\sigma$ is the intentemporal elasticity of substitution in full consumption. $\mathrm{C}$ is a CES composite of consumption of goods and services $\mathcal{C}$ and leisure $\ell$ :

$$
C_{1}=\left[\bar{C}^{\frac{u-1}{v}}+\alpha_{c}^{\frac{1}{v}} e^{\frac{u-1}{v}}\right] \frac{u}{v-1}
$$

$v$ is the elasticity of substitution between goods and leisure; $\alpha_{c}$ is an intensity parameter for leisure.

The variable $e$ in (25) is a Cobb-Douglas aggregate of 17 composite consumer goods:

$$
\widetilde{C}_{i}=\prod_{i=1}^{17} \bar{C}_{i, i}
$$

where the $\alpha_{c, d}(i=1, \ldots, 17)$ are parameters. The 17 types of consumer goods identified in the model are shown

${ }^{5}$ For a discussion of alternative specifications, see Poterba and Summers (1985).

$$
A-8
$$


in Table 2 of the main text.

Consumer goods are produced domestically and abroad. Each composite consumer good $\bar{C}_{i}, i=1, \ldots, 17$. is a CES aggregate of a domestic and foreign consumer good of a given type:

$$
\bar{C}=\gamma_{i}\left[\alpha_{i}=C D^{p \cdot}+\left(1-\alpha_{i}\right) C F^{p_{c}}\right]^{1 / p_{i}}
$$

In the above equation, $C D$ and $C F$ denote the household's consumption of domestically produced and foreign made consumer good of a given type at a given point in time. For simplicity, we have omitted subscripts designating the type of consumer good and the time period.

The household maximizes utility subject to the intertemporal budget constraint given by the following condition governing the change in financial wealth, $W K$ :

$$
W K_{r, 1}-W K_{1}=\bar{r}_{t} W K_{1}+Y L_{1}+G T_{1}-\tilde{p}, \bar{C}
$$

In the above equation, $\bar{r}$ is the average after-tax retum on the household's portfolio of financial capital, $Y L$ is after-tax labor income, $G T$ is transfer income, and $p$ is the price index representing the cost to the household of a unit of the consumption composite, $C$.

\section{Government Behavior}

A single government sector approximates government activities at all levels - federal, state, and local. The main activities of the government sector are purchasing goods and services (both non-durable and durable), to transferring incomes, and to raising revenue through taxes or bond issue.

\section{Components of Government Expenditure}

Government expenditure, $G$, divides into nominal purchases of nondurable goods and services $(G P)$, nominal govemment investment $(G D$, and nominal transfers $(G D)$ :

$$
G_{\imath}=G P_{1}+G I_{t}+G T_{\imath}
$$

In the reference case, the paths of real $G P, G I$, and $G T$ all are specified as growing at the steady-state real growth rate, $g$. In simulating policy changes we fix the paths of $G P, G I$, and $G T$ so that the paths of real government purchases, investment and transfers are the same as in corresponding years of the reference case. Thus, the expenditure side of the government ledgei is largely kept unchanged across simulations. This procedure is expressed by:

$$
\begin{aligned}
& G P_{t}^{p} / P_{G P . t}^{p}=G P_{t}^{R} / P_{G P, 1}^{R} \\
& G I_{1}^{p} / P_{G L_{1}}^{p}=G l_{1}^{R} / P_{G L_{1}}^{R}
\end{aligned}
$$




$$
G T_{1}^{p} / P_{C T, 1}^{p}=G T_{1}^{R} / P_{G T, 1}^{R}
$$

The superscripts $P$ and $R$ denote policy change and reference case magnitudes, while $p_{t i p}, p_{t i t}$ and $p_{t i r}$ are price indices for $G P . G I$, and $G T$. The price index for govemment investment, $P_{G I}$, is the purchase price of the representative capital good. The price index for transfers, $p_{G r}$, is the consumer price index. The index for govemment purchases. $p_{i ; p}$, is defined below.

\section{Allocation of Government Purchases}

$G P$ divides into purchases of particular outputs of the 13 domestic industries according to fixed expenditure shares:

$$
\alpha_{G i} G P=G P X_{i} p_{1}
$$

$G P, X_{i}$ and $p_{i}$ are the quantity demanded and price of output from industry $i$, and $\alpha_{f, j}$ is the corresponding expenditure share. The ideal price index for government purchases, $p_{C P}$, is given by:

$$
p_{r ; p}=\prod_{i=1}^{n} p_{i}^{\alpha_{v}}
$$

\section{I. Parameter Values}

A. Elasticities of Substitution in Production

$\begin{array}{lllllll}\begin{array}{l}\text { Parameter: } \\ \text { Substitution }\end{array} & \sigma_{1} & \sigma_{11} & \sigma_{2} & \sigma_{\mathrm{\varepsilon}} & \sigma_{\mathrm{m}} & \sigma_{、} \\ \text { margin: } & g_{1}-g_{1} & \text { L-K } & \text { E-M } & \begin{array}{l}E \text { com- } \\ \text { ponents }\end{array} & \begin{array}{l}M \text { com- } \\ \text { ponents }\end{array} & \begin{array}{l}\text { dom-foreign } \\ \text { inputs }\end{array}\end{array}$

Producing Industry:

1. Agric. \& Non-coal
Mining

2. Coal Mining

3. Oil \& Gas Extraction

4. Synthetic Fuels

5. Petroleum Refining

6. Electric Utilities

7. Gas Utilities

8. Construction
0.7

0.7

0.7

0.7

0.7

0.7

0.7

0.7
0.68

0.80

0.82

0.82

0.74

0.81

0.96

0.95
0.7

0.7

0.7

0.7

0.7

0.7

0.7

0.7 


\begin{tabular}{|c|c|c|c|c|c|c|}
\hline 9. Metals \& Machinery & 0.7 & 0.91 & 0.7 & 1.21 & 0.6 & 2.74 \\
\hline 10. Motor Vehicles & 0.7 & 0.80 & 0.7 & 1.04 & 0.6 & 1.14 \\
\hline $\begin{array}{l}\text { 11. Misc. } \\
\text { Manufacturing }\end{array}$ & 0.7 & 0.94 & 0.7 & 1.08 & 0.6 & 2.74 \\
\hline $\begin{array}{l}\text { 12. Services (excepl } \\
\text { housing) }\end{array}$ & 0.7 & 0.98 & 0.7 & 1.07 & 0.6 & 1.0 \\
\hline 13. Housing Services & 0.7 & 0.80 & 0.7 & 1.81 & 0.6 & (not traded) \\
\hline
\end{tabular}

B. Parameters of Stock Effect Function in Oil and Gas Industry

$\begin{array}{lcccc}\text { Parameter: } & \mathrm{Z}_{v} & \overline{\mathrm{Z}} & \varepsilon_{1} & \varepsilon_{:} \\ \text {Value: } & 0 & 450 & 1.27 & 2.0\end{array}$

Note: This function is parameterized so that $y_{i}$ approaches 0 as $Z$ approaches $\bar{Z}$ (see equation (8)). The value of $\bar{Z}$ is 450 billion barrels (about 100 times the 1990 production of oil and gas, where gas is measured in barrelequivalents.) $\vec{Z}$ is based on estimates from Masters et al. (1987). Investment in new oil and gas capital ceases to be protitable before reserves are depleted: the values of $\varepsilon_{1}$ and $\varepsilon_{2}$ imply that, in the baseline scenario, oil and gas investment becomes zero in the year 2031.

C. Utility Function Parameters

Parameter:

Value:
(1)

0.007 $\sigma$

0.5 $v$

0.69 $\eta$

0.84 
Figure 1

Consumption of Oil \& Gas and Synthetic Fuels

(eva':uated at 1990 prices)

billions of dollars

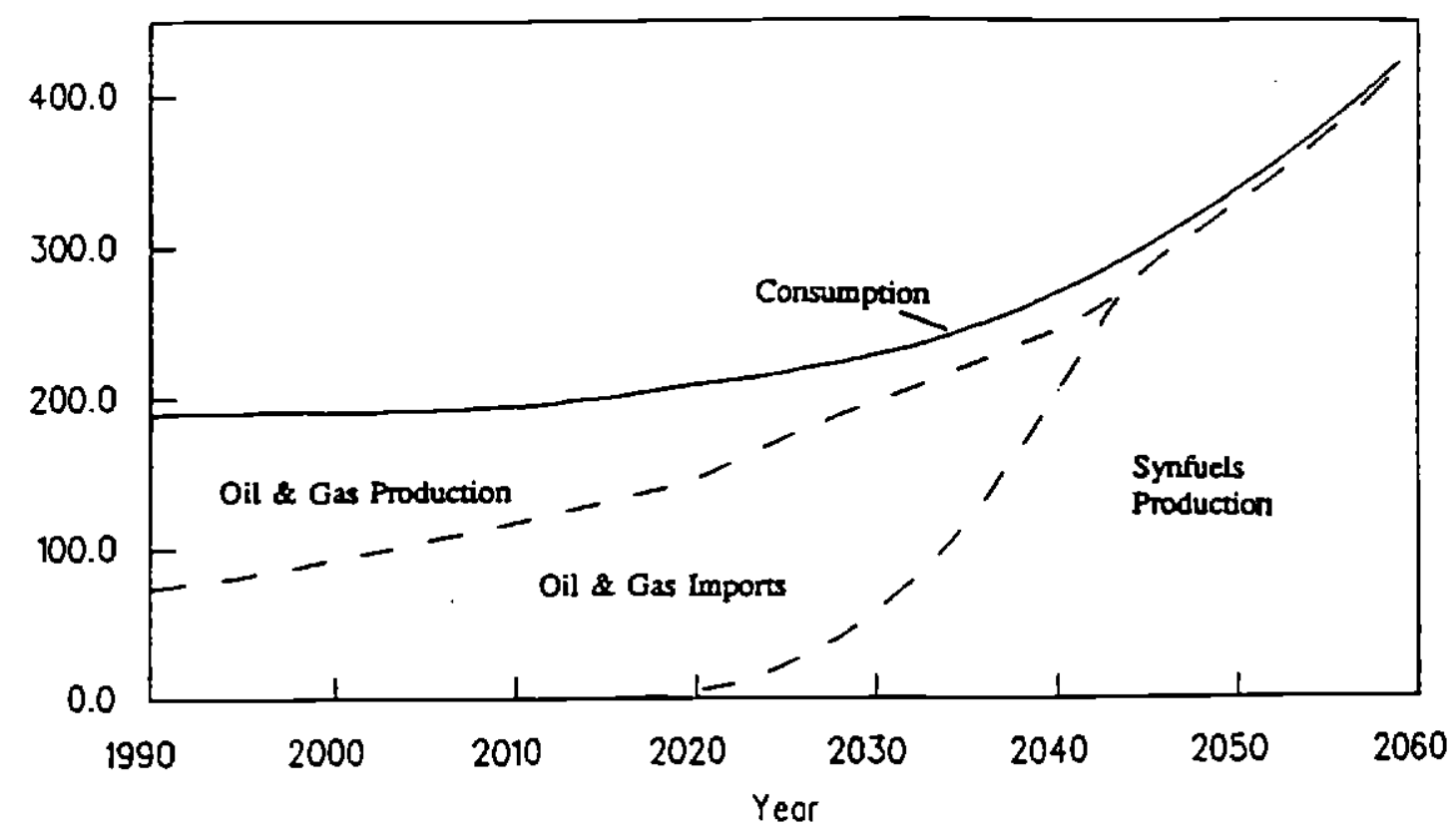


Figure 2

Marginal Welfare Costs. Emissions Reductions and Carbon Tax Rates

a)

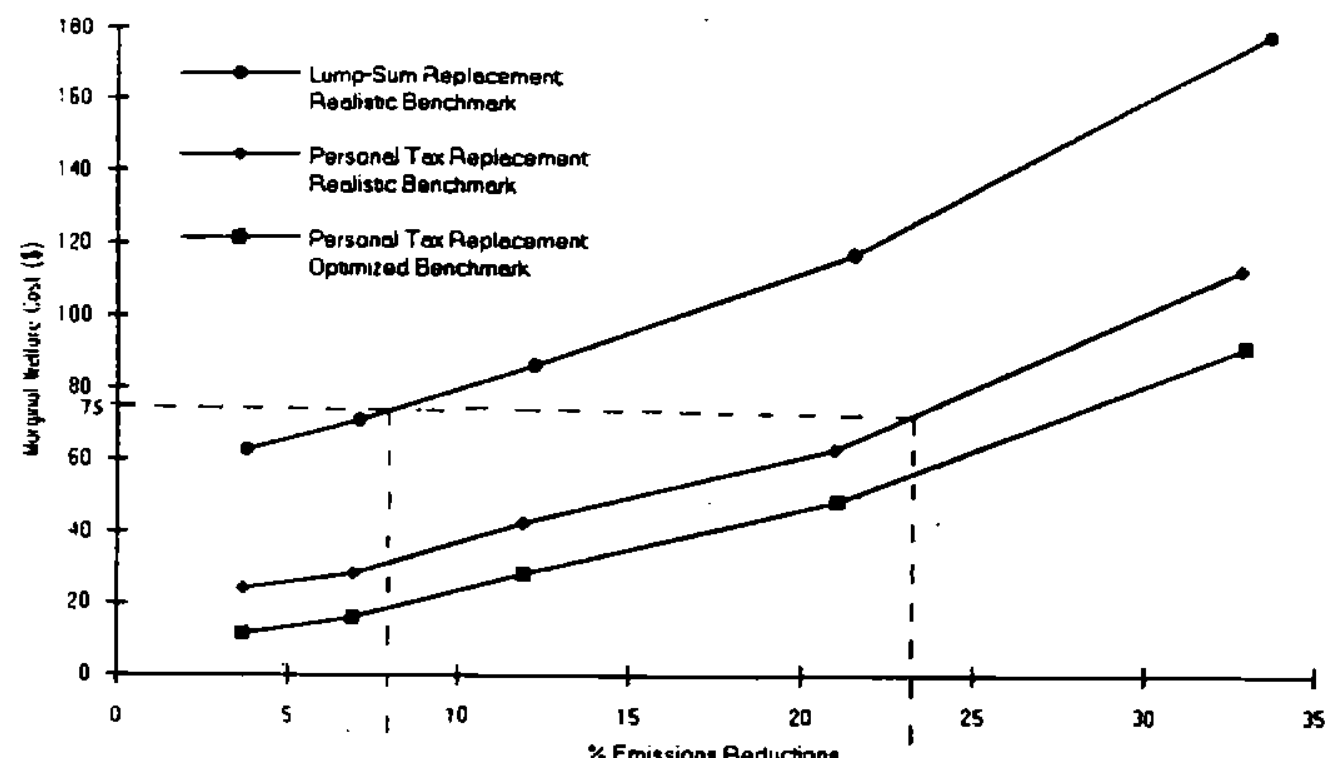

b)

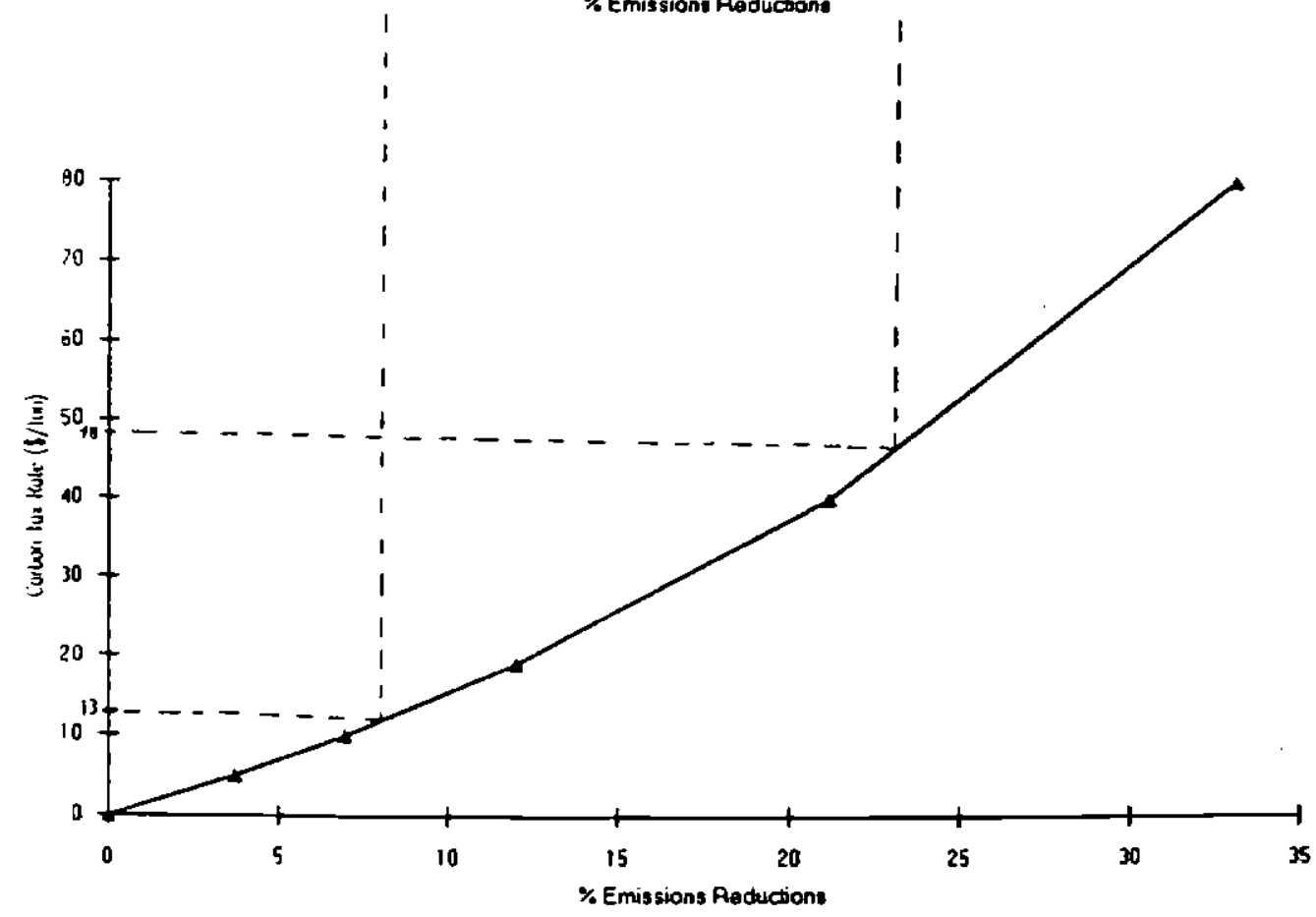


Table 1

Industry and Consumer Good Categories

Industries

1. Agriculture and Non-Coal Mining

2. Coal Mining

3. Crude Petroleum and Nanural Gas

4. Synthetic Fuels

5. Petroleum Refining

6. Electric Utilities

7. Gas Utilities

8. Construction

9. Metals and Machinery

10. Motor Vehicles

11. Miscellaneous Manufacturing

12. Services (except housing)

13. Housing Services

\section{Consumer Goods}

1. Food

2. Alcohol

3. Tobacco

4. Utilities

5. Housing Services

6. Furnishings

7. Appliances

8. Clothing and Jewelry

9. Transportation

10. Motor Vehicles

11. Services (except financial)

12. Financial Services

13. Recreation, Reading, \& Misc.

14. Nondurable, Non-Food Household Expenditure

15. Gasoline and Other Fuels

16. Education

17. Health 
Table 2

Differences between Pigovian and Second-Best Taxes

(All tax rales in dollars per ton)

\begin{tabular}{|c|c|c|c|c|c|}
\hline & \multirow[b]{2}{*}{$\begin{array}{l}\text { "Optimal" } \\
\text { Pigovian } \\
\text { Tax }\end{array}$} & \multirow{2}{*}{$\begin{array}{l}\text { Optimal Tax } \\
\text { Implied by } \\
\text { Analytical } \\
\text { Model } \\
\text { (PIT } \\
\text { Replacement) }\end{array}$} & \multicolumn{3}{|c|}{$\begin{array}{c}\text { Optimal Tax } \\
\text { from Numerical Model }\end{array}$} \\
\hline & & & $\begin{array}{c}\text { Realistic } \\
\text { Benchmark. } \\
\text { Lump-Sum } \\
\text { Replacement }\end{array}$ & $\begin{array}{c}\text { Realistic } \\
\text { Benchmark, } \\
\text { PIT } \\
\text { Replacement }\end{array}$ & $\begin{array}{c}\text { Optimized } \\
\text { Benchmark. } \\
\text { PIT } \\
\text { Replacement }\end{array}$ \\
\hline \multicolumn{6}{|c|}{$\begin{array}{l}\text { Assumed } \\
\text { Marginal } \\
\text { Environmental } \\
\text { Damages: } \\
\text { (\$/ton) }\end{array}$} \\
\hline 25 & 25 & 22 & 0 & 7 & 17 \\
\hline 50 & so & 45 & 0 & 27 & 41 \\
\hline 75 & 75 & 67 & 13 & 48 & 64 \\
\hline 100 & 100 & 89 & 31 & 68 & 85 \\
\hline
\end{tabular}


Table 3: Sensitivity Analysis ${ }^{1}$

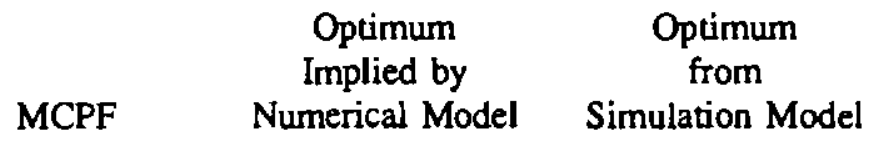

1. Central Case

1.121

67

48

2. Marginal Rates for

Pre-existing Taxes

-- lowered 50\%

1.036

72

64

- raised 50\%

1.194

63

34

3. Intertemporal Elasticity

of Substitution in

Consumption ${ }^{2}$

-- low (.33)

1.102

68

52

-. high (.66)

1.146

65

45

4. Uncompensated Elasticity of Labor Supply ${ }^{3}$

- low $(-0.03)$

1.149

68

44

-- high (0.16)

1.149

65

54

5. Energy Substitution Elasticities

-- lowered by $50 \%$

1.107

1.173

68

50

-. raised by $50 \%$

64

44

'Marginal environmental benefits are assumed to be $575 \mathrm{hon}$. Results for the numerical model are from sinulations of a carbon tax with revenue-preserving reductions in marginal rates of the personal income tax.

${ }^{2}$ Central case value is 0.5 .

'These simulations involve changes in $v$, the goods-leisure elasticity of substitution. The central case value of $v$ is 0.69 , implying an uncompensated labor supply elasticity of 0.06 . $v$ is 0.64 and 0.74 in the low and high elasticity cases. The compensated elasticities in the low, central and high cases are $0.45,0.52$, and 0.63 , respectively.

In the low (high) elasticity simulation, the elasticity of substitution between composite energy (E) and composite materials $(\bar{M})$ is lowered (raised) in all industries by 50 percent 